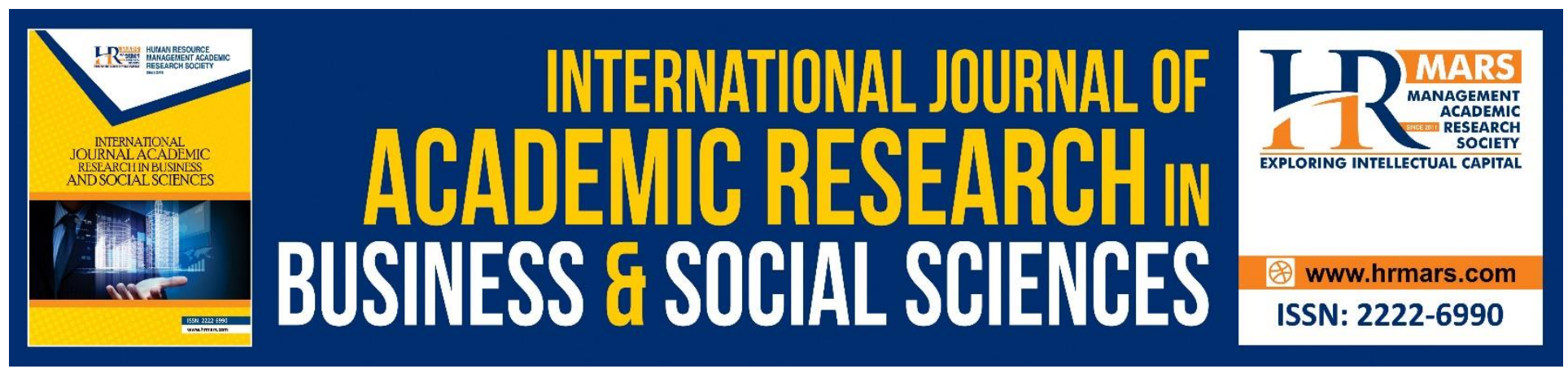

\title{
Restaurant Performance from the Perspective of Top Management of Malay Restaurant: A Construct Validity Study
}

\author{
Mohd Syaifuddin Mohd Alias, Hashim Fadzil Ariffin, Raja Puteri Saadiah Raja \\ Abdullah
}

To Link this Article: http://dx.doi.org/10.6007/IJARBSS/v11-i13/8515

DOI:10.6007/IJARBSS/v11-i13/8515

Received: 06 November 2020, Revised: 08 December 2020, Accepted: 27 December 2020

Published Online: 20 January 2021

In-Text Citation: (Alias et al., 2021)

To Cite this Article: Alias, M. S. M., Ariffin, H. F., \& Abdullah, R. P. S. R. (2021). Restaurant Performance from the Perspective of Top Management of Malay Restaurant: A Construct Validity Study. International Journal of Academic Research in Business and Social Sciences, 11(13), 195-205.

Copyright: () 2021 The Author(s)

Published by Human Resource Management Academic Research Society (www.hrmars.com)

This article is published under the Creative Commons Attribution (CC BY 4.0) license. Anyone may reproduce, distribute, translate and create derivative works of this article (for both commercial and non-commercial purposes), subject to full attribution to the original publication and authors. The full terms of this license may be seen

at: $\underline{\text { http://creativecommons.org/licences/by/4.0/legalcode }}$

Special Issue: Beyond 2021 and COVID-19 - New Perspective in the Hospitality \& Tourism Industry, 2021, Pg. 195 - 205 http://hrmars.com/index.php/pages/detail/IJARBSS JOURNAL HOMEPAGE

Full Terms \& Conditions of access and use can be found at http://hrmars.com/index.php/pages/detail/publication-ethics 


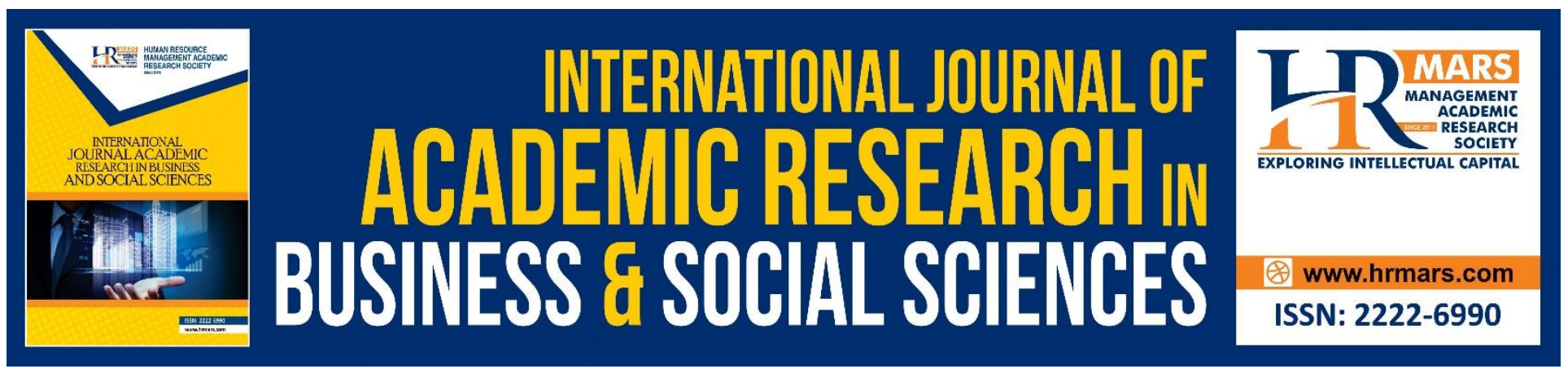

\title{
Restaurant Performance from the Perspective of Top Management of Malay Restaurant: A Construct Validity Study
}

\author{
Mohd Syaifuddin Mohd Alias ${ }^{1}$, Hashim Fadzil Ariffin², Raja Puteri \\ Saadiah Raja Abdullah ${ }^{1}$ \\ ${ }^{1}$ Faculty of Hotel and Tourism Management, Universiti Teknologi MARA, Puncak Alam Campus, \\ 42300, Selangor, Malaysia, ${ }^{2}$ Faculty of Hotel and Tourism Management, Universiti Teknologi MARA, \\ Penang Campus, 14000, Bukit Mertajam, Pulau Pinang, Malaysia
}

\begin{abstract}
It is important for Malay restaurants to maintain their products and services, process, management, as well as marketing strategies to compete with other competitors. Hence, the influence of human capital to apply innovation practices can enhance the productivity of the restaurant and increase its performance. Experience and education are important to expand knowledge, skills, and new ideas towards the development of a restaurant. Innovation practices run as a mediator that contributes to the sustainability of the restaurant. A survey questionnaire was conducted with a total of 507 respondents among the top management of Malay restaurants from Kuala Lumpur and Selangor. The results from the study revealed that restaurant performance is important for the development and sustainability of their restaurants. The results also indicated that profitability, growth and satisfaction will lead to restaurant performance. Above all, top management need to have an influence on restaurant performance so that business development can be achieved.
\end{abstract}

Keywords: Malay Restaurant, Innovation Practices, Human Capital, Malay Restaurant Performance, Resource Based-View Theory

\section{Introduction}

Restaurant performance (RP) among Malay restaurant businesses have been a major concern due to the failure of their quality (Abdullah et al., 2017). The main reason of their closure relates to the operation inefficiency that uses the same conservative structure in management and technology without acknowledging the innovation practices that can be applied for future development. With the technological trend shifting into a new dimension, the trend of dining also changes, highlighting the new trend of eating-out that is becoming an obsession (Chahal \& Kamil, 2017). As the trend grows, restaurant handlers need to think of a way to improve their quality of services, food, and technology, 
or by placing their incentives in a positive light through the restaurant ambience (Nikbin, Marimuthu, \& Hyun, 2016). Enz (2004) mentioned the relationship quality between employees and restaurant owners are always the biggest challenges and it arises frequently. The restaurant owners are to blame as they cannot afford to maintain the current workers for a long period which leads to a higher turnover rate among the employees.

Once the management disobeys the main part of the development, then it will cause mismanagement that can lead towards closure. For example, the Anuar Kari Kepala Ikan restaurant closed down due to its mismanagement and hygiene problems for 14 days (Mamat, 2020). Other examples of Malay restaurants that went through closure phase were the Tudung Periuk restaurant that belonged to the Malaysian actress Ning Baizura (Mahmud, 2019), and the 1Market restaurant owned by a Malaysian celebrity chef, Chef Wan (Astro Awani, 2018). Despite these restaurants having potential for belonging to popular and influential personalities in Malaysia, were deficient of quality communication, mismanagement, issues in menu preparation, and effective marketing that result towards bad perceptions towards these restaurants. On another perspective, these internal factors may need the intervention of innovation practices as the main strategy to call for restaurant accountability specifically in management, marketing, product, service and process (Abdullah et al., 2017). In addition, Yoshino (2010) explained that Malay food and restaurants fail to resemble as a Malaysian symbolism when the Malays themselves have difficulties in distinguishing Malay food, and are uncertain with their decision to find reasonable terms to represent the food itself. The terms are usually vague and ambiguous, and the definitions are rather unclear.

Horng, Chou, Liu, and Tsai (2013) mentioned that factors like innovative ideas, creativity, and knowledge can together create a proper foundation for the restaurant performance while sustaining the businesses. On top of that, the involvement of human capital intertwines with the application of innovation practices and restaurant performances. Nevertheless, there have been limited number of studies on the influence of human capital and mediating effect of innovation practices towards Malay business restaurant performance. In other words, to what extent does the human capital and innovation practices are involved with the development and sustainability of Malay business restaurant to gain better performance. Meanwhile, the dimensions of human capital namely experience and education involvement has not been widely discussed, though being significant to innovation practices and restaurant performances. Generally, there are limited published and unpublished studies relating to Malay business restaurant.

\section{Literature Review}

\section{Malay Restaurant Performance}

As stated by Kasim and Ismail (2012), the environment of the restaurant will have a big impact to the restaurant performance as it brings ambience to the surroundings and improve customers' experience. While performance is the main indicator, the improvement process needs to have some knowledge and certain skills to be developed as it can benefit the company internally and externally (Heo, 2017). Innovations may improve company performance as it needs every aspect of measurement to begin the company structure (Lee et al., 2016). Innovation is useful to the current businesses as it designs modern solutions to solve current issues involving the company performance. 
Restaurant performances are also related to human capitals, in which it uses resources in the businesses to develop its performance. Knowledge, experience, and skills are among resources that benefit the restaurant performance (Aidis \& van Praag, 2007; Fayolle \& Gailly, 2015; Hadjimanolis, 2000; Sondari, 2014). There are three major constructs in restaurant performance, namely profitability, growth, and satisfaction of performance.

\section{Profitability}

Mun and Jang (2015) elaborated that the management efficiency especially in operative performance may positively impact the profitability of the restaurant. Mun and Jang (2018) also highlighted other major points including the firm size, financial stability, market competitiveness, and other issues that may hinder a strong accountability in the restaurant performance. Erkuş-Öztürk and Terhorst (2016) described the growth of the restaurant services depends on the mass visitor of locals and foreigners in one particular country, state or even area. It contributes to the cultural exchange in one particular culture that had been visited by the foreign people.

\section{Growth}

According to Terhorst and Erkuş-Öztürk (2018), the diversification of the traditions and national identity in the kitchen possibly affects the growth and the development of the performance in restaurants. When a management opens room for exchanging ideas and opinions with their employees, it will build a closer bond between the two parties and the positive interaction between them will then singlehandedly boost the performance and development of the organization (Perramon, Alonso-Almeida, Llach, \& Bagur-Femenías, 2014). The organization can also benefit from employees' positive working experience that is developed by the influence of the operational, production and service structure (Jogaratnam, 2017). Above all, the influence of top management and innovation practices in restaurant development could lead to the satisfaction of its performance.

\section{Satisfaction with Performance}

Gagic (2016) highlighted that restaurants had significantly improved their performances after taking initiatives to apply innovation practices, which in return maximized their profit. Other than that, Hallak, Assaker, O'Connor, and Lee (2018) in their research have recognized the importance of innovation and creativity to successfully manage a restaurant in efforts to boost its performance. Bufquin, DiPietro, Park, and Partlow (2017) had researched about the importance of maintenance of the human capital. Employees in particular, can interact better when they are working in a friendly environment with good ambience, and all-rounded and experienced colleagues as it can directly impact the restaurant performances. In other cases, Koys and DeCotiis (2015) in their research have found that a good interaction between the employees and their employers creates a positive environment in the restaurant, directly affecting their overall restaurant performance. These findings explained how the surroundings especially management contributes most to the satisfaction in the workplace.

\section{Methodology}

In order to validate the suitability and reliability of the restaurant performance construct, a descriptive research design was applied. The population for this study focused on top management - namely the 
owners, managers, and assistant managers of Malay restaurants in Klang Valley and Selangor. The data was collected using the snowball sampling method. Two phases of data collection were conducted, specifically pilot study and field study. The data were collected using personally administered questionnaires. In total, 507 respondents had successfully answered the questionnaires given. For research instrument, restaurant performance contains three constructs and 15 items measured using 7-Likert scale (from 1-strongly disagree, 2-disagree, 3-somewhat disagree, 4-neutral, 5-somewhat agree, 6-agree, 7-strongly agree).

A hypothesis structural model consisting of profitability, growth, and satisfaction of performance is proposed for this study. These three constructs work as exogenous variables, whereas restaurant performance runs as an endogenous variable. Based on the constructs, three hypotheses are taken from the structural model of the study. The hypotheses are as follows:

$\mathrm{H}_{1}$. Profitability as a construct of restaurant performance

$\mathrm{H}_{2}$. Growth as a construct of restaurant performance

$\mathrm{H}_{3}$. Satisfaction of performance as a construct of restaurant performance

\section{Findings}

\section{Confirmatory Factor Analysis}

\section{Convergent Validity}

According to Hair et al. (2010); Byrne (2010); and Pallant (2010), the Chi-square statistic is referred as the scale of whether the measure used is good or bad. Chi-square is the traditional measure to evaluate the overall model fit in covariance. They mentioned further that a good model fit would be stated as $p>0.05$. To identify whether the model fit is good or bad, the measurement breaks down into two values, whereby small $\times 2$ - values represent the bad fit, and large $\times 2$ - values represents a good fit. The degree of freedom as a standard by which to access chi-square is marked as small or large. Other than that, the assessment of the goodness of fit concluded by Hair et al. (2010), Byrne (2010); Ernest et al. (2008) used CMIN/df, GFI, P, and RMSEA to analyze the whole model whether it is good or bad. The rule of thumb of the cutoff point also been used only for the model analysis. Table 2 below shows the assessment of the goodness of fit: 
INTERNATIONAL JOURNAL OF ACADEMIC RESEARCH IN BUSINESS AND SOCIAL SCIENCES

Vol. 11, No. 13, Beyond 2021 and COVID-19 - New Perspective in the Hospitality \& Tourism Industry. 2021, E-ISSN: 2222-6990 @ 2021 HRMARS

Table 2: Assessment of goodness of fit

\begin{tabular}{ll}
\hline Types of constructs & Cut-off \\
\hline Chi-square (X2) & Smaller to 0 \\
Degree of freedom (df) & \\
CMIN/df & $\leq 2-5$ \\
Goodness of fit index (GFI) & $\geq 0.90$ \\
Probability (P) & $\geq 0.05$ \\
Root mean squared error of approximation (RMSEA) & $\leq 0.08$ \\
\hline
\end{tabular}

Source: Hair et al. (2010), Byrne (2010), and Ernest et al. (2008)

Campbell and Fiske (1959) suggested that as a basis of reasoning, convergent validity is closely related to latent variable that measure the values between variables, and indicators will be validated whether it is perfect or not suitable for the construct. In short, convergent validity is an s-verification that needs to be done to get an appropriate result (Gaskin, 2016). If there is no convergence, the items need to be erased in order to get a perfect result. Other than that, discriminant validity also needs to be conducted. Discriminant validity is one of the requirements to measure the coefficient of correlation among the components (Gaskin, 2016). The result of restaurant performance convergent validity is shown in Table 3.

Table 3: Results of First Order CFA

\begin{tabular}{ccccccc}
\hline Variables & $\begin{array}{c}\text { Chi- } \\
\text { Square } \chi 2\end{array}$ & $\begin{array}{c}\text { Degree of } \\
\text { freedom (df) } \\
\text { Restaurant Performance }\end{array}$ & Ratio & $\begin{array}{c}\text { Goodness of } \\
\text { fit index (GFI) }\end{array}$ & P-Value & RMSEA \\
\hline Profitability & 7.156 & 2 & 3.578 & 0.994 & 0.028 & 0.071 \\
Growth & 1.714 & 1 & 1.714 & 0.998 & 0.190 & 0.038 \\
Satisfaction & 1.948 & 1 & 1.948 & 0.998 & 0.163 & 0.043 \\
\hline
\end{tabular}

The second order of CFA was conducted to analyze the restaurant performance as a latent construct. Based on the results shown in table 4 below, second order analysis has been run successfully. Three constructs have been analyzed with 11 items. The constructs were profitability, growth and satisfaction with performance.

Table 4: Results of Second Order CFA

\begin{tabular}{ccccccc}
\hline $\begin{array}{c}\text { Model Fit } \\
\text { Indicator }\end{array}$ & $\begin{array}{c}\text { Chi-Square } \\
\chi^{2}\end{array}$ & $\begin{array}{c}\text { Degree of } \\
\text { freedom } \\
\text { (df) }\end{array}$ & Ratio & $\begin{array}{c}\text { Goodness of } \\
\text { fit index } \\
\text { (GFI) }\end{array}$ & P-Value & RMSEA \\
\hline Value & 138.119 & 35 & 3.946 & 0.955 & 0.000 & 0.076 \\
\hline
\end{tabular}

Table above shows the goodness of fit of restaurant performance model $\left(\chi^{2}=138.119, \mathrm{df}=35\right.$, Ratio $=3.946, \mathrm{GFI}=0.955, \mathrm{P}$-Value $=0.000$, and RMSEA $=0.076)$. Through second order CFA analysis, it has been confirmed that three constructs of restaurant performance with 11 items used in the study is valid. 


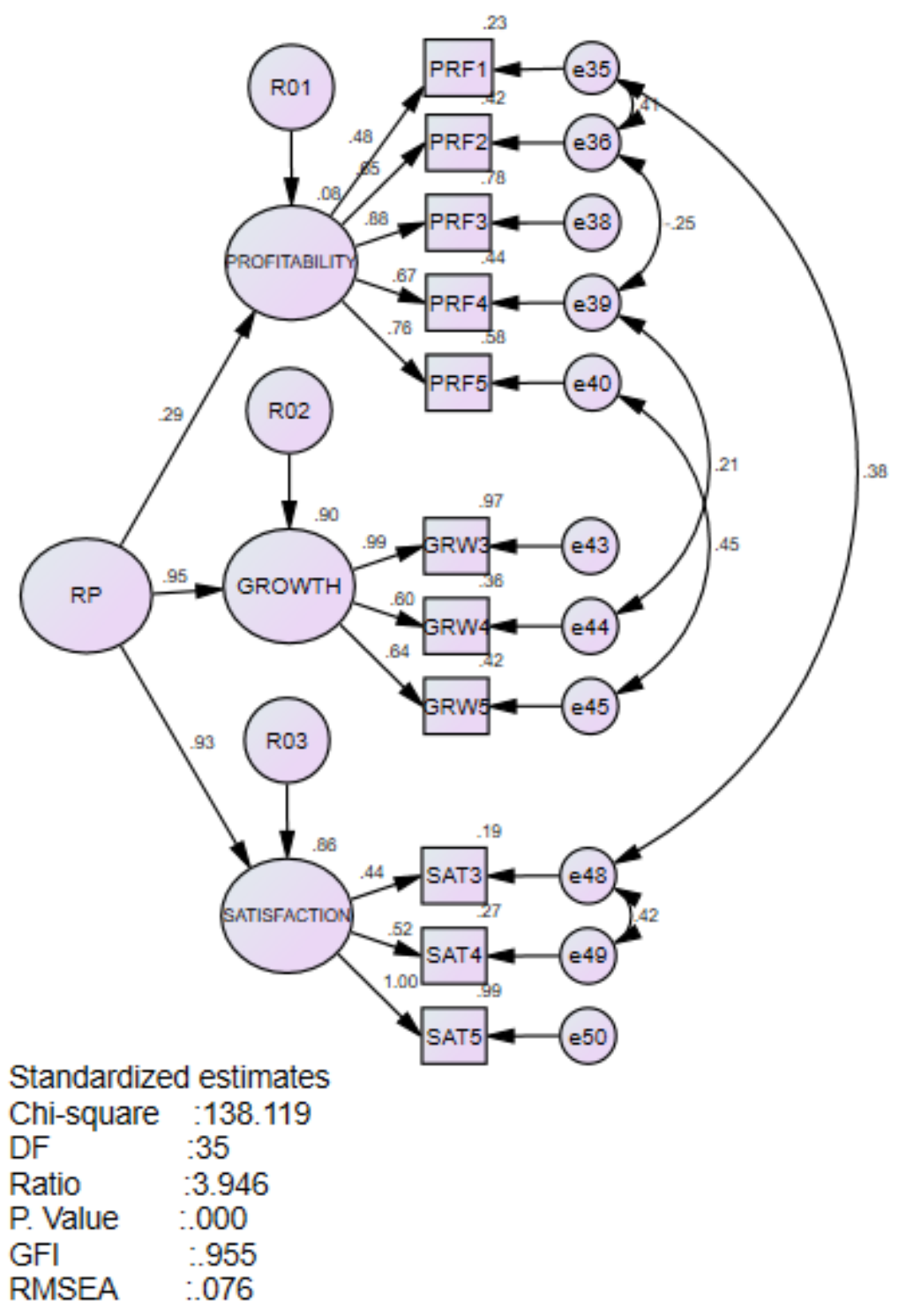

Figure 1: Second Order CFA of Restaurant Performance

\section{Reliability Tests}

By using SEM AMOS, coefficient alpha can be extracted. Table 5 below shows the result of composite reliability and average variance extracted of the construct. According to Fornell and Larckell (1981), average variance extracted measures "amount of variance that is captured by the construct in relation to the amount of variance due to measurement error". AVE should be considered as to capture variance in the items than measurement error. But, Fornell and Larcker (1981) mentioned about the AVE less than 0.5 is acceptable if the composite reliability (CR) is higher than 0.6. Thus, the convergent validity of the construct still adequate for the study. This statement supported by Lam (2012) and Hair, Black, Babin and Tatham (2009) which indicate the AVE less than 0.5 is acceptable but need to looking at the CR value must be greater than 0.6 . 
INTERNATIONAL JOURNAL OF ACADEMIC RESEARCH IN BUSINESS AND SOCIAL SCIENCES

Vol. 11, No. 13, Beyond 2021 and COVID-19 - New Perspective in the Hospitality \& Tourism Industry. 2021, E-ISSN: $2222-6990$ ๑ 2021 HRMARS

Table 5: Variance Extracted and Construct Reliability Test

\begin{tabular}{|c|c|c|c|c|c|}
\hline Construct & Item & Factor Loading & $\mathrm{Cr}$ & Ave & $\begin{array}{c}\text { Convergent } \\
\text { Validity }\end{array}$ \\
\hline \multirow[t]{5}{*}{ PROFITABILITY } & PRF1 & 0.476 & 0.821 & 0.488 & YES \\
\hline & PRF2 & 0.646 & & & \\
\hline & PRF3 & 0.881 & & & \\
\hline & PRF4 & 0.665 & & & \\
\hline & PRF5 & 0.763 & & & \\
\hline \multirow[t]{3}{*}{ GROWTH } & GRW3 & 0.986 & 0.797 & 0.581 & YES \\
\hline & GRW4 & 0.596 & & & \\
\hline & GRW5 & 0.645 & & & \\
\hline SATISFACTION & SAT3 & 0.439 & 0.711 & 0.485 & YES \\
\hline WITH & SAT4 & 0.518 & & & \\
\hline PERFORMANCE & SAT5 & 0.997 & & & \\
\hline
\end{tabular}

The results in Table 7 indicates that CR and AVE as well as convergent validity (CV) for restaurant performance construct has achieved the minimum acceptable values as referred to Fornell and Larcker (1981). Therefore, to conclude the study, CR, AVE and CV of restaurant performance has achieved the acceptable values.

\section{Results of Hypothesis Testing and Variance Explained (Squared Multiple Correlations)}

Table 8 below shows the results of hypothesis testing and variance explained for restaurant performance construct as an endogenous variable, and profitability, growth and satisfaction of performance as exogenous variables. The confirmed hypothesis for restaurant performance is PRF $(\beta=0.093, C R=5.425, P>0.000), G R W(\beta=0.701, C R=17.669, P>0.000)$ and $S A T(\beta=0.253, C R=9.260$, $\mathrm{P}>0.000)$.

Table 8: Results of Hypothesis Testing and Variance Explained (Squared Multiple Correlations)

\begin{tabular}{|c|c|c|c|c|c|c|c|}
\hline & Exogenous & Endogenous & $\begin{array}{l}\text { Std } \\
\text { Estimates }\end{array}$ & Std Error & CR & SMC & $\mathrm{P}$ \\
\hline $\mathrm{H} 1$ & PRF & $\mathrm{RP}$ & 0.093 & 0.017 & 5.425 & 0.085 & 0.000 \\
\hline $\mathrm{H} 2$ & GRW & $\mathrm{RP}$ & 0.701 & 0.040 & 17.669 & 0.900 & 0.000 \\
\hline H3 & SAT & $\mathrm{RP}$ & 0.253 & 0.027 & 9.260 & 0.860 & 0.000 \\
\hline
\end{tabular}

\section{Discussions and Conclusions}

This study requires researcher to confirm the model fit of restaurant performance. Eventually, all constructs have been taken as a part of RP. The constructs have been reorganized to fit in to Malay restaurant context which could bring success to Malay restaurant businesses. We believe that this model will be useful in the future managerial research and practice for these businesses.

\section{Acknowledgment}

This study was funded by, Universiti Teknologi MARA, Malaysia (UiTM). 


\section{Corresponding Author}

Mohd Syaifuddin Mohd Alias.

Faculty of Hotel and Tourism Management, Universiti Teknologi MARA, Puncak Alam Campus, 42300, Selangor, Malaysia.

Email: syfdnalias@gmail.com

\section{References}

Abdullah, R. P. S. R., Ariffin, H. F., Mohi, Z., \& Anuar, N. A. M. (2017). Assessing the internal factors of Malay ethnic restaurants business growth performance. Journal of Tourism, Hospitality \& Culinary Arts, 9(2), 517-528.

Aidis, R., \& Van Praag, M. (2007). Illegal entrepreneurship experience: Does it make a difference for business performance and motivation? Journal of Business Venturing, 22(2), 283-310.

Bufquin, D., DiPietro, R., Park, J. Y., \& Partlow, C. (2017). Effects of social perceptions and organizational commitment on restaurant performance. Journal of Hospitality Marketing and Management, 26(7), 752-769. https://doi.org/10.1080/19368623.2017.1293580

Byrne, B. M. (2010). Structural Equation Modeling with AMOS: Basic concepts, applications, and programming.

Campbell, D. T., \& Fiske, D. W. (1959). Convergent and discriminant validation by the multitraitmultimethod matrix. Psychological Bulletin, 56(2), 81-105. https://doi.org/10.1037/h0046016

Chahal, D. K., \& Kamil, N. M. (2017). The determinants of customer satisfaction and behavioral intention among restaurants in Klang Valley area of Malaysia: A conceptual study. E-Bangi, 14(2), 307-317.

Erkuş-Öztürk, H., \& Terhorst, P. (2016). Innovative restaurants in a mass-tourism city: Evidence from Antalya. Tourism Management, 54, 477-489. https://doi.org/10.1016/j.tourman.2016.01.003

Ernest, L. H. (2008). Basic Analysis: A guide for student and researchers. Kuching, Sarawak: Jade Tree Press.

Fornell, C., \& Larcker, F. (1981). Evaluating structural equation model with unobservable variables and measurement error. Journal of Marketing Research, 18(1), 39 - 50. https://doi.org/10.2307/3151312

Fayolle, A., \& Gailly, B. (2015). The impact of entrepreneurship education on entrepreneurial attitudes and intention: Hysteresis and persistence. Journal of Small Business Management, 53(1), 75-93. https://doi.org/10.1111/jsbm.12065

Gagic, S. (2016). Restaurant innovativeness: A case study of Vojvodina. The European Journal of Applied Economics, 13(2), 57-69. https://doi.org/10.5937/ejae13-10503

Gaskin, J. (2016). Convergent Validity. Gaskination's StatWiki. Retrieved October 12, 2020, from http://statwiki.kolobkreations.com

Hadjimanolis, A. (2000). An investigation of innovation antecedents in small firms in the context of a small developing country. R\&D Management, 30(3), 235-245. https://doi.org/10.1111/14679310.00174

Hair, J. F., Black, W. C., Anderson, R. E., \& Tatham, R. L. (2009). Multivariate Data Analysis (7 $7^{\text {th }}$ ed.). Pearson Education Limited.

Hair, J. F., Black, W. C., Babin, B. J., \& Anderson, R. E. (2017). Multivariate Data Analysis (MVDA). In Pharmaceutical Quality by Design: A Practical Approach. 
INTERNATIONAL JOURNAL OF ACADEMIC RESEARCH IN BUSINESS AND SOCIAL SCIENCES

Vol. 11, No. 13, Beyond 2021 and COVID-19 - New Perspective in the Hospitality \& Tourism Industry. 2021, E-ISSN: 2222-6990 @ 2021 HRMARS

Hallak, R., Assaker, G., O'Connor, P., \& Lee, C. (2018). Firm performance in the upscale restaurant sector: The effects of resilience, creative self-efficacy, innovation and industry experience. Journal of Retailing and Consumer Services, 40, 229-240. https://doi.org/10.1016/j.jretconser.2017.10.014

Heo, C. Y. (2017). New performance indicators for restaurant revenue management: ProPASH and ProPASM. International Journal of Hospitality Management, 61, 1-3. https://doi.org/10.1016/j.ijhm.2016.10.005

Horng, J. S., Chou, S. F., Liu, C. H., \& Tsai, C. Y. (2013). Creativity, aesthetics and eco-friendliness: A physical dining environment design synthetic assessment model of innovative restaurants. Tourism Management, 36, 15-25. https://doi.org/10.1016/j.tourman.2012.11.002

Jogaratnam, G. (2017). How organizational culture influences market orientation and business performance in the restaurant industry. Journal of Hospitality and Tourism Management, 31, 211-219. https://doi.org/10.1016/j.jhtm.2017.03.002

Kasim, A., \& Ismail, A. (2012). Environmentally friendly practices among restaurants: Drivers and barriers to change. Journal of Sustainable Tourism, 20(4), 551-570. https://doi.org/10.1080/09669582.2011.621540

Koys, D. J., \& DeCotiis, T. A. (2015). Does a good workforce influence restaurant performance or does good restaurant performance influence the workforce?. Journal of Human Resources in Hospitality and Tourism, 14(4), 339-356. https://doi.org/10.1080/15332845.2015.1008370

Lam, L. W. (2012). Impact of competitiveness on salespeople's commitment and performance. Journal of Business Research, 65(9), 1328 - 1334. https://doi.org/10.1016/j.jbusres.2011.10.026

Lee, C., Hallak, R., \& Sardeshmukh, S. R. (2016). Innovation, entrepreneurship, and restaurant performance: A higher-order structural model. Tourism Management, 53, 215-228. https://doi.org/10.1016/j.tourman.2015.09.017

Mahmud, F. S. (2019). Ning Baizura tutup restoran selepas tiga bulan beroperasi. Berita Harian. Retrieved from https://www.bharian.com.my/hiburan/selebriti/2019/04/547503/ningbaizura-tutup-restoran-selepas-tiga-bulan-beroperasi

Mamat, N. S. (2020). Restoran Anuar kari kepala ikan bawah pokok diarah tutup. Astro Awani. Retrieved from http://www.astroawani.com/berita-malaysia/restoran-anuar-kari-kepala-ikanbawah-pokok-diarah-tutup-230413

Mun, S. G., \& Jang, S. (2015). Working capital, cash holding, and profitability of restaurant firms. International Journal of Hospitality Management, 48, 1-11. https://doi.org/10.1016/j.ijhm.2015.04.003

Mun, S. G., \& Jang, S. (2018). Restaurant operating expenses and their effects on profitability enhancement. International Journal of Hospitality Management, 71, 68-76. https://doi.org/10.1016/j.ijhm.2017.12.002

Nikbin, D., Marimuthu, M., \& Hyun, S. S. (2016). Influence of perceived service fairness on relationship quality and switching intention: an empirical study of restaurant experiences. Current Issues in Tourism, 19(10), 1005-1026. https://doi.org/10.1080/13683500.2013.801407

Pallant, J. (2011). A Step by step guide to data analysis using SPSS program survival manual 4th edition. 
Perramon, J., Alonso-Almeida, M. del M., Llach, J., \& Bagur-Femenías, L. (2014). Green practices in restaurants: Impact on firm performance. Operations Management Research, 7(1-2), 2-12. https://doi.org/10.1007/s12063-014-0084-y

Sondari, M. C. (2014). Is entrepreneurship education really needed?: Examining the antecedent of entrepreneurial career intention. Procedia - Social and Behavioral Sciences, 115, 44-53. https://doi.org/10.1016/j.sbspro.2014.02.414

Terhorst, P., \& Erkuş-Öztürk, H. (2018). Carriers of change and continuity: New restaurants in Amsterdam. Tijdschrift Voor Economische En Sociale Geografie, 109(1), 144-160. https://doi.org/10.1111/tesg.12266

Yoshino, K. (2010). Malaysian Cuisine: A case of neglected culinary globalization. In Globalization, Food and Social Identities in the Asia Pacific Region, 1-13. http://icc.fla.sophia.ac.jp/global\%20food\%20papers/html/yoshino.html 